\title{
Applications of Social Network Analysis in Evaluation: Challenges, Suggestions, and Opportunities for the Future
}

\author{
Joanne G. Carman \\ University of North Carolina-Charlotte
}

Kimberly A. Fredericks

The Sage Colleges

\begin{abstract}
As the use of social network analysis in evaluation continues to increase, it is important to understand how, when, and under what conditions social network analysis can add value to evaluation work. In this article, we describe how we have used social network analysis in various evaluation projects. Using the experience of one specific project, we highlight, in greater detail, some challenges we encountered in doing this work, relating to the need for stakeholders to understand the added value of social network analysis, the intricacies of data coding and cleaning, and how changes in the size and scope of the project can have great implications. Finally, we offer some practical suggestions for evaluators considering incorporating social network analysis into their work today, and identify opportunities where evaluators might use social network analysis in the future.
\end{abstract}

Keywords: data coding and cleaning, outcomes evaluation, process evaluation, social network analysis

Resumé : Avec la croissance de l'utilisation, en évaluation, de l’analyse des réseaux sociaux, il est important de comprendre quand, comment, et dans quelles conditions l'analyse des réseaux sociaux apporte une valeur ajoutée. Dans le présent article, nous décrivons la façon dont nous avons utilisé lanalyse des réseaux sociaux dans le cadre de divers projets dévaluation. À partir de l'expérience d’un projet particulier, nous décrivons, de façon détaillée, certains des défis auxquels nous avons fait face, notamment en ce qui concerne la nécessité, pour les parties prenantes, de comprendre la valeur ajoutée de l'analyse des réseaux sociaux, les complexités du codage et du nettoyage des données et les implications des changements dans la taille et la portée du projet. Finalement, nous faisons quelques suggestions pratiques pour les évaluateurs qui pensent inclure l'analyse des réseaux sociaux dans leurs travaux actuels et nous identifions des pistes, pour les évaluateurs, pour l'utilisation future de ce type d'analyse.

Mots clés : codage et nettoyage de données, évaluation des résultats, évaluation des processus, analyse des réseaux sociaux

Corresponding author: Joanne G. Carman, Department of Political Science and Public Administration, University of North Carolina-Charlotte, 9201 University City Blvd., Charlotte, NC, 28223, USA; jgcarman@uncc.edu

(C) 2018 Canadian Journal of Program Evaluation / La Revue canadienne d'évaluation de programme 33.2 (Fall / automne), 175-187 doi: 10.3138/cjpe.31156 
As the use of social network analysis in evaluation continues to increase, it is important to understand how, when, and under what conditions social network analysis can add value to evaluation work. In an effort to build on the small but growing literature about social network analysis and evaluation, this article describes how we have used social network analysis in our evaluation work. In reflecting upon one project in greater detail, we describe the challenges we experienced, as they relate to stakeholder engagement, project planning, data collection, data cleaning and coding, and project management. Finally, we offer practical suggestions for evaluators considering incorporating social network analysis into their work, and identify opportunities where evaluators might use social network analysis in the future.

\section{SOCIAL NETWORK ANALYSIS AND EVALUATION}

Social network analysis (SNA) in evaluation has grown considerably in recent years. As Johnson, Honnold, and Stevens (2010, p. 494) explain, "SNA is a descriptive social science methodology that maps, measures, and finds patterns in the connections between people and/or organizations." Because SNA focuses on the relationships between individuals, groups, and organizations, it can help evaluators better understand the context of a program or initiative, as well as the underlying relationships that are fundamental to the work (Fredericks, 2005).

A review of the literature finds that some evaluators are using SNA to assist with various aspects of evaluation and organizational development work, ranging from assessing capacity-building efforts and examining organizational performance (Fredericks, 2005; Luque et al., 2010) to exploring policy networks and advocacy efforts (Drew, Aggleton, Chalmers, \& Wood, 2011; Honeycutt \& Strong, 2012). SNA is also helping evaluators understand the complexities and drivers of organizational collaboration (Cross, Dickmann, Newman-Gonchar, \& Fagan, 2009; Woodland \& Hutton, 2012), as well as communication, knowledge, and information sharing (Birk, 2005; Eglene, Dawes, \& Schneider, 2007; Hambrick, 2017).

While these studies highlight the findings from SNA, some authors describe the challenges of using SNA. For example, the nature of the case study, small sample sizes, and low survey response rates can be problematic and limit generalizability (Lahdelma \& Laakso, 2016; Luke, Baumann, Carothers, Landsverk, \& Proctor, 2016). Grunspan, Wiggins, and Goodreau (2014) describe how some of the technical details matter, such as the need to clean the data and keep the attribute data in the same order as the matrix data. The purpose of this article is to further explore these types of challenges.

\section{APPLICATIONS}

During the past 14 years, we have worked on more than 25 projects involving SNA and evaluation. Our role on these projects has varied. For 15 projects, we served as the evaluators, using SNA as a tool to assist with the larger evaluation of a program or initiative. Typically, SNA was used as part of a process evaluation, in 
a formative way, highlighting opportunities to improve information sharing, communication, or collaboration within the context of a specific program or initiative. A few projects were focused on outcomes, where SNA was used to track changes in a particular network over time.

For some projects, we served as evaluation consultants, providing technical assistance to foundations or government agencies interested in funding projects involving SNA. We helped them to draft requests for proposals, assisted with the proposal review process, and helped with the interpretation of the analysis and findings. For other projects, we helped nonprofit organizations and foundations improve the way they used SNA. This included providing technical assistance about how to collect network data (e.g., creating surveys and interview guides), store and manipulate data (e.g., building databases, creating matrices), and analyze data using different SNA software programs (e.g., UCINET, ORA, Gephi; see Gephi, 2017; ORA-PRO, 2017; UCINET, 2017). We also offered trainings, including half-day workshops, full-day workshops, demonstration talks at professional meetings, and participated in learning communities convened by foundations (see Table 1).

Table 1: Authors' Experience with Social Network Analysis

\begin{tabular}{|c|c|c|c|c|}
\hline Year & Partner & Role & $\begin{array}{l}\text { Type of } \\
\text { Evaluation }\end{array}$ & Experience \\
\hline 2003 & $\begin{array}{l}\text { University } \\
\text { research team }\end{array}$ & Evaluator & $\begin{array}{l}\text { Process \& } \\
\text { outcomes }\end{array}$ & $\begin{array}{l}\text { Conducted SNA as part } \\
\text { of an evaluation }\end{array}$ \\
\hline 2005 & $\begin{array}{l}\text { Federal govern- } \\
\text { ment agency }\end{array}$ & $\begin{array}{l}\text { Technical } \\
\text { assistance }\end{array}$ & $\begin{array}{l}\text { Process \& } \\
\text { outcomes }\end{array}$ & $\begin{array}{l}\text { Created the RFP for SNA } \\
\text { project }\end{array}$ \\
\hline 2007 & $\begin{array}{l}\text { Philanthropic } \\
\text { foundation }\end{array}$ & $\begin{array}{l}\text { Technical } \\
\text { assistance }\end{array}$ & $\begin{array}{l}\text { Process \& } \\
\text { outcomes }\end{array}$ & $\begin{array}{l}\text { Provided technical assist- } \\
\text { ance for the evaluation }\end{array}$ \\
\hline 2008 & $\begin{array}{l}\text { State govern- } \\
\text { ment agency }\end{array}$ & Evaluator & Process & $\begin{array}{l}\text { Conducted SNA as part } \\
\text { of an evaluation }\end{array}$ \\
\hline 2009-10 & $\begin{array}{l}\text { Philanthropic } \\
\text { foundation }\end{array}$ & $\begin{array}{l}\text { Technical } \\
\text { assistance }\end{array}$ & $\begin{array}{l}\text { Process \& } \\
\text { outcomes }\end{array}$ & $\begin{array}{l}\text { Provided technical assist- } \\
\text { ance for the evaluation }\end{array}$ \\
\hline 2009-10 & $\begin{array}{l}\text { Philanthropic } \\
\text { foundation }\end{array}$ & Evaluator & Outcomes & $\begin{array}{l}\text { Conducted SNA as part } \\
\text { of an evaluation }\end{array}$ \\
\hline 2009-12 & $\begin{array}{l}\text { Nonprofit } \\
\text { organization }\end{array}$ & Evaluator & Outcomes & $\begin{array}{l}\text { Conducted SNA as part } \\
\text { of an evaluation }\end{array}$ \\
\hline 2009-12 & $\begin{array}{l}\text { Nonprofit } \\
\text { organization }\end{array}$ & Evaluator & Process & $\begin{array}{l}\text { Conducted SNA as part } \\
\text { of an evaluation }\end{array}$ \\
\hline 2010 & $\begin{array}{l}\text { Philanthropic } \\
\text { foundation }\end{array}$ & Training & $n / a$ & $\begin{array}{l}\text { Led full-day workshops } \\
\text { and a symposium }\end{array}$ \\
\hline 2010-11 & $\begin{array}{l}\text { Nonprofit } \\
\text { organization }\end{array}$ & Evaluator & Process & $\begin{array}{l}\text { Conducted SNA as part } \\
\text { of an evaluation }\end{array}$ \\
\hline
\end{tabular}


Table 1: Continued

\begin{tabular}{|c|c|c|c|c|}
\hline Year & Partner & Role & $\begin{array}{l}\text { Type of } \\
\text { Evaluation }\end{array}$ & Experience \\
\hline 2010-11 & $\begin{array}{l}\text { Philanthropic } \\
\text { foundation }\end{array}$ & $\begin{array}{l}\text { Technical } \\
\text { assistance }\end{array}$ & $\begin{array}{l}\text { Process \& } \\
\text { outcomes }\end{array}$ & $\begin{array}{l}\text { Provided technical assist- } \\
\text { ance for the evaluation }\end{array}$ \\
\hline 2010-11 & $\begin{array}{l}\text { Nonprofit } \\
\text { organization }\end{array}$ & Trainer & $\mathrm{n} / \mathrm{a}$ & $\begin{array}{l}\text { Led full-day workshops } \\
\text { and a symposium }\end{array}$ \\
\hline 2010-13 & $\begin{array}{l}\text { Nonprofit } \\
\text { organization }\end{array}$ & Evaluator & Process & $\begin{array}{l}\text { Created surveys, data } \\
\text { analysis }\end{array}$ \\
\hline 2010-13 & $\begin{array}{l}\text { Professional } \\
\text { association }\end{array}$ & Trainer & $\mathrm{n} / \mathrm{a}$ & $\begin{array}{l}\text { Led half- and full-day } \\
\text { workshops }\end{array}$ \\
\hline 2011 & $\begin{array}{l}\text { Philanthropic } \\
\text { foundation }\end{array}$ & Evaluator & Process & $\begin{array}{l}\text { Conducted SNA as part } \\
\text { of an evaluation }\end{array}$ \\
\hline 2011-12 & $\begin{array}{l}\text { Evaluation } \\
\text { consulting firm }\end{array}$ & $\begin{array}{l}\text { Technical } \\
\text { assistance }\end{array}$ & Process & Created a survey \\
\hline 2012 & $\begin{array}{l}\text { Philanthropic } \\
\text { foundation }\end{array}$ & $\begin{array}{l}\text { Technical } \\
\text { assistance }\end{array}$ & Process & $\begin{array}{l}\text { Created the RFP for SNA } \\
\text { project }\end{array}$ \\
\hline 2012 & $\begin{array}{l}\text { Evaluation } \\
\text { consulting firm }\end{array}$ & Evaluator & $\begin{array}{l}\text { Process \& } \\
\text { outcomes }\end{array}$ & $\begin{array}{l}\text { Conducted SNA as part } \\
\text { of an evaluation }\end{array}$ \\
\hline 2012 & $\begin{array}{l}\text { Philanthropic } \\
\text { foundation }\end{array}$ & $\begin{array}{l}\text { Technical } \\
\text { assistance }\end{array}$ & $\begin{array}{l}\text { Process \& } \\
\text { outcomes }\end{array}$ & $\begin{array}{l}\text { Provided technical assist- } \\
\text { ance for the evaluation }\end{array}$ \\
\hline $2012-13$ & $\begin{array}{l}\text { Evaluation } \\
\text { consulting firm }\end{array}$ & Evaluator & Process & $\begin{array}{l}\text { Created a survey, did the } \\
\text { analysis }\end{array}$ \\
\hline $2012-13$ & $\begin{array}{l}\text { Philanthropic } \\
\text { foundation }\end{array}$ & $\begin{array}{l}\text { Technical } \\
\text { assistance }\end{array}$ & $\begin{array}{l}\text { Process \& } \\
\text { outcomes }\end{array}$ & $\begin{array}{l}\text { Provided technical assist- } \\
\text { ance for the evaluation }\end{array}$ \\
\hline 2013 & $\begin{array}{l}\text { Philanthropic } \\
\text { foundation }\end{array}$ & $\begin{array}{l}\text { Technical } \\
\text { assistance }\end{array}$ & $\begin{array}{l}\text { Process \& } \\
\text { outcomes }\end{array}$ & $\begin{array}{l}\text { Provided technical assist- } \\
\text { ance for the evaluation }\end{array}$ \\
\hline 2013 & $\begin{array}{l}\text { Philanthropic } \\
\text { foundation }\end{array}$ & Evaluator & Process & $\begin{array}{l}\text { Provided technical assist- } \\
\text { ance for the evaluation }\end{array}$ \\
\hline 2013 & $\begin{array}{l}\text { University } \\
\text { research team }\end{array}$ & Evaluator & $\begin{array}{l}\text { Process \& } \\
\text { outcomes }\end{array}$ & $\begin{array}{l}\text { Conducted SNA as part } \\
\text { of an evaluation }\end{array}$ \\
\hline 2013 & $\begin{array}{l}\text { Nonprofit } \\
\text { organization }\end{array}$ & Evaluator & Outcomes & $\begin{array}{l}\text { Conducted SNA as part } \\
\text { of an evaluation }\end{array}$ \\
\hline $2013-14$ & $\begin{array}{l}\text { Philanthropic } \\
\text { foundation }\end{array}$ & $\begin{array}{l}\text { Technical } \\
\text { assistance }\end{array}$ & $\begin{array}{l}\text { Process \& } \\
\text { outcomes }\end{array}$ & $\begin{array}{l}\text { Provided technical assist- } \\
\text { ance for the evaluation }\end{array}$ \\
\hline 2015 & $\begin{array}{l}\text { Federal govern- } \\
\text { ment agency }\end{array}$ & Evaluator & Process & $\begin{array}{l}\text { Conducted SNA as part } \\
\text { of an evaluation }\end{array}$ \\
\hline 2016 & $\begin{array}{l}\text { Nonprofit } \\
\text { organization }\end{array}$ & $\begin{array}{l}\text { Technical } \\
\text { assistance }\end{array}$ & Outcomes & $\begin{array}{l}\text { Provided technical assist- } \\
\text { ance for the evaluation }\end{array}$ \\
\hline $\begin{array}{l}\text { 2015- } \\
\text { present }\end{array}$ & $\begin{array}{l}\text { Nonprofit } \\
\text { organization }\end{array}$ & Evaluator & Process & $\begin{array}{l}\text { Conducted SNA as part } \\
\text { of an evaluation }\end{array}$ \\
\hline $\begin{array}{l}\text { 2016- } \\
\text { present }\end{array}$ & $\begin{array}{l}\text { Professional } \\
\text { association }\end{array}$ & Trainer & $\mathrm{n} / \mathrm{a}$ & $\begin{array}{l}\text { Led half- and full-day } \\
\text { workshops }\end{array}$ \\
\hline
\end{tabular}


For one project, we were hired by the Robert Wood Johnson Foundation to conduct a social network analysis of a strategic advisory committee convened to oversee and provide leadership for one of the foundation's major initiatives. The purpose of the SNA was to evaluate the capacity of the advisory committee to provide information and leverage resources for the initiative. A six-member evaluation team was assembled to carry out the work. Planning, data collection, and data analysis for the project lasted almost one year. Data collection involved conducting interviews with 23 individuals associated with the advisory committee. The interviewees were asked open-ended questions about their personal and professional networks. The interviews were recorded and transcribed. To assemble the data for the SNA, each transcript was reviewed to identify the names and organizational affiliations of each member of the network. These data were compiled into spreadsheets, transformed into matrices, and exported into UCINET software for data analysis. The interview data were also supplemented with archival data gathered from the interviewees' resumes and other documents, which were also compiled into the spreadsheets. The final report described the social networks among the advisory committee members, highlighting the strengths and noting the gaps, and concluded with recommendations to improve the network. In this article, we describe the challenges we experienced, as they relate to stakeholder engagement, project planning, data collection, data cleaning and coding, and project management.

\section{SOCIAL NETWORK ANALYSIS CHALLENGES}

Throughout the project, the evaluation team encountered challenges relating to planning and data collection, data cleaning and coding, and project management.

\section{Planning and data-collection challenges}

During the planning and data-collection phases of the project, there were three challenges relating to buy-in and full participation from advisory committee members, the reluctance of some advisory members to talk in great detail about their networks, and the need to streamline the original interview guide.

\section{Buy-in and full participation}

In writing the project's proposal, the evaluation team recognized that it would be challenging to get senior executive leaders to meet with the evaluation team for an interview. To accommodate this challenge, the evaluation team planned to schedule personal interviews around the advisory committee meetings. Given the sensitive nature of the questions (asking people to identify personal and professional connections), the evaluation team also recognized that conducting personal interviews would create greater rapport with the committee members and yield better information (as opposed to creating a survey, which is often used to gather data for SNA). The advisory committee, however, met only twice as a group, and the evaluation team was invited to just one of these meetings. 
At the meeting, the foundation's program officer originally had 30 minutes to explain the purpose of the SNA and introduce the evaluation team. The meeting, however, was cut short due to the threat of extreme weather and concerns about travel plans. The program officer was given only a few minutes to describe the SNA project, and the evaluation team was unable to conduct many of the scheduled interviews. Not having an opportunity to fully explain the purpose of the SNA project and illustrate the potential benefits contributed to some confusion about the types of data the evaluation team was looking for, as well as to the reluctance among some members to fully identify, disclose, and describe all of their relationships. As a result, the social networks for some advisory committee members were not fully captured.

\section{Reluctance of participants to "name names"}

Regardless of whether the advisory committee members understood the purpose and potential benefits of the project, the nature of the questions we were asking proved to be sensitive for some of the committee members. While there has been little research about this particular facet of SNA, the evaluation team found that some of the high-level executives we interviewed were simply reluctant to share information about their personal and professional networks.

\section{Pre-testing data-collection instruments}

The importance of pre-testing the data-collection instruments was reaffirmed in this project. The initial draft of the interview guide contained 28 questions, and interviewees were asked to discuss who participates in their communication, collaboration, and advisory networks. After the interview guide was pre-tested with two advisory committee members, it was clear that the guide needed to be shorter, and the way in which the questions were initially framed (looking at relationships in terms of communication, collaboration, or advisory) did not resonate with how advisory committee members thought about their personal and professional networks. The questions were rephrased to use more general language, such as "With respect to this project, who have you worked with in the last six months?" or "With whom do you share important information?"

\section{Challenges related to data coding and cleaning}

During the data-coding and-cleaning process, there were four challenges: the labor-intensive process of transcribing the interviews, integrating the information from résumés and other data sources, and creating the spreadsheets; coding the attribute data; cleaning the data; and creating the matrices to export the data in the required format.

\section{Transcribing interview data and creating spreadsheets}

The audio files from each interview were transcribed into text by members of the evaluation team. A Microsoft Excel spreadsheet was then created for each advisory member. The spreadsheets included the first and last names of each person in the network, their position, and their organizational affiliation. The audio files, 
transcripts, and spreadsheets were reviewed independently by two other members of the evaluation team and checked for fidelity and accuracy. Where discrepancies were found, another member of the evaluation team reviewed the files until consensus was reached. When interviewees used acronyms, or unfamiliar names, organizations or terms, the evaluation team conducted follow-up research to identify and clarify the names of the individuals and organizations. In some cases, the evaluation team checked back with the interviewees for clarification. The evaluation team also conducted Internet and document research to verify and validate the relationships and affiliations.

Transcribing the data and creating the spreadsheets proved to be more laborintensive than expected. While the interviews lasted between 30 minutes and one hour, it took two to three hours to transcribe each interview. It took approximately 20 hours for the two-member teams to review an audio file, transcript, and spreadsheet to check for fidelity and accuracy, as well as additional time if a third team member needed to review the data.

\section{Coding data}

Once the data were assembled, the evaluation team needed to code the attributes of organizations and individuals. The evaluation team had assembled a set of pre-codes to code the attribute data based on codes being used in other SNA projects being funded by the foundation (so comparisons could be made). About one-third of the way into the coding process, the evaluation team realized that not only was there a reliability issue, with team members coding similar data differently, but the pre-codes also were not specific enough to describe the network in enough detail. The evaluation team then used an inductive approach to coding, allowing the codes to emerge from the data. This was an iterative process. The final coding scheme for the attributes was much more detailed. For example, more than 85 codes were created to capture the types of organizations in the network, compared to the original eight codes.

\section{Cleaning data}

In preparing the data for the SNA, the evaluation team needed to make sure that the individuals' names and organizational affiliations were identified and described in exactly the same way throughout the data set, and the team had to ensure that there were no duplicate references. Formatting of the data needed to be consistent (e.g., data could be entered using "Sentence case" or "Title Case," but not both). All position descriptions needed to be consistent (e.g., using the descriptor of "board member," and not "member of the board" or "member of the board of directors").

\section{Creating matrices}

The networks among the interviewees ranged from fewer than 20 connections for one committee member to more than 1,000 connections for another. This created an initial challenge when it came time to transpose the aggregated data to create the matrices. The solution was to convert the flat data file (one spreadsheet with all 
of the aggregated data) into a set of relational data tables (one for each interviewee in Microsoft Access), and use the reporting software Tableau to run crosstab reports (whereby the output was in the necessary matrix form). The crosstab reports were saved as Microsoft Excel files and imported into UCINET for analysis.

\section{Challenges related to project management}

The evaluation team also encountered challenges relating to project management. While these are not necessarily unique challenges, they are worth mentioning: accommodating the expanding size and scope of the project, working under a tight timeframe, and communicating the findings.

\section{Accommodating the expanding size and scope of the project}

In the initial proposal, the evaluation team expected to conduct interviews with 10-12 advisory committee members. As the project unfolded, the size and scope of the project expanded by more than $50 \%$. The evaluation team interviewed not only all 14 of the advisory committee members, but also seven representatives from the foundation and two key stakeholders who served as advisors to the initiative outside of the foundation. While the team wanted to be accommodating to the foundation and get the best information for the project, this expansion made for additional work.

\section{Working under a tight timeframe}

From the very beginning, the project had a very tight timeframe. The initial proposal called for six months, but the project lasted for almost one year. There were delays at the beginning of the project, with the foundation being late in awarding the grant, and there were delays in getting the advisory committee members' contact information. Scheduling the interviews with advisory board members was difficult due to busy schedules. More time was spent transcribing, coding, and analyzing the data than anticipated.

\section{Communicating the final results}

While the final report and presentation to the foundation included more than 30 network maps and information about centrality measures, the data were also presented in ways that were more recognizable and understandable for readers. For example, the report included frequency tables, lists of the most frequent and less frequent types of connections, and geographic maps. In addition, the final report and presentation were prefaced by a tutorial and explanation of the different types of networks found in the study (e.g., Hub or Star, Hybrid Hubs with Small or Large Groups, Hub of Groups, and a Complete Network) so that readers could better understand the findings.

\section{SUGGESTIONS}

Hatry \& Newcomer (2016) offer a checklist of 27 pitfalls to avoid in evaluation. While this list is comprehensive and worth reviewing before the start of any new 
evaluation project, we would like to offer some suggestions for evaluators seeking to add SNA to their evaluation endeavors. These include the following:

1. Explain what SNA is to the project participants at the beginning, and show how it will add value to the project.

2. While surveys can be an efficient way of gathering social network data, take advantage of other data-collection methods, if needed, such as interviews, archival documents, meeting minutes, and résumés, as these can be valuable ways for collecting and validating network data.

3. Secure the highest participation rates as possible so that networks maps are complete.

4. Specify clear data-coding and -formatting guidelines at the beginning of the project, and be sure to check the data for duplicates, errors, reliability, and validity.

5. Pre-test data-collection instruments, and avoid lengthy surveys or interview protocols.

6. Translate the findings for different stakeholders, recognizing that network maps, by themselves, are not usually sufficient.

7. Be realistic about the size and scope of the project, recognizing that some projects may be too big for SNA.

8. Be open to the idea that SNA might not be the right application (e.g., perhaps a stakeholder-assessment or systems-mapping approach would be more useful).

While most of these suggestions are well documented in the research and evaluation-design literature (Alaimo, 2008; Babbie, 2012; Bryson \& Patton, 2010; Newcomer, Hatry, \& Wholey, 2016; Thomas, 2010), they are also important for evaluators to consider if they are incorporating SNA into their work.

\section{OPPORTUNITIES FOR FUTURE PRACTICE}

Moving forward, we think there are opportunities to use SNA in many different evaluation contexts. For example, because public health and social service problems (e.g., teen pregnancy, obesity, literacy) remain intractable, we are seeing a rise in cross-sector, collaborative initiatives that bring together government agencies, nonprofit organizations, philanthropic organizations, and the private sector, as well as citizen engagement initiatives (Flood, Minkler, Lavery, Estrada, \& Falbe, 2015; Kottke, Levine, Schlanger, \& Nolte, 2015; Ledley, Gold, Niepold, \& McCaffrey, 2014; Nahlen \& Low-Beer, 2007). While many of these initiatives have a strong focus on measurable outcomes and improving community-level indicators, evaluators can also use SNA as part of a process evaluation, to identify who is participating in these efforts, how they are doing so, and who is missing, and to make recommendations for improving these initiatives. 
Other opportunities to use SNA might include multisite projects where the context of programs varies (Fredericks, Carman, \& Birkland, 2002); programs that provide information, outreach, or referral services (Bartholomay, Chazdon, Marczak, \& Walker, 2011); knowledge-mobilization efforts (Donnelly \& Searle, 2017); online and in-person learning communities (Olsen \& Olsen, 2014); instructional development in college programs (Kapucu, Yuldashev, Demiroz, \& Arslan, 2010); or mentoring programs (Aylward, Odar, Kessler, Canter, \& Roberts, 2012). Essentially, any evaluation project where successful outcomes depend upon the resources, information, and connections between individuals and organizations could be a suitable platform for SNA. SNA also complements empowerment evaluation and transformative evaluation approaches (Fetterman \& Wandersman, 2005; Mertons, 2008).

The increasing recognition of the value of social networks and relationships (Carrington, Scott, \& Wasserman 2005; Christakis \& Fowler, 2009) makes it likely that the use of SNA is only going to continue to grow. In addition to interest among foundations and government agencies, the Canadian Evaluation Society, the American Evaluation Association, and many other professional associations across specific disciplines (e.g., public health, sociology, community psychology) are providing professional development workshops, webinars, and other training opportunities for evaluators, as well as other researchers, relating to the theories, methods, and applications of SNA. Moreover, SNA software is more widely available and affordable, making it more likely that SNA will be a tool that evaluators will use in their work (Knoke \& Yang, 2008).

\section{REFERENCES}

Alaimo, S.P. (2008). Nonprofits and evaluation: Managing expectations from the leader's perspective. In J.G. Carman \& K.A. Fredericks (Eds.), Nonprofits and evaluation. New Directions for Evaluation, 119, 73-92. San Francisco, CA: Jossey Bass. https:// doi.org/10.1002/ev.269

Aylward, B.S., Odar, C.C., Kessler, E.D., Canter, K.S., \& Roberts, M.C. (2012). Six degrees of separation: An exploratory network analysis of mentoring relationships in pediatric psychology. Journal of Pediatric Psychology, 37(9), 972-979. https://doi.org/10.1093/ jpepsy/jss078

Babbie, E. (2012). The practice of social research (13th ed.). Independence, KY: Cengage Learning.

Bartholomay, T., Chazdon, S., Marczak, M.S., \& Walker, K. (2011). Mapping Extension's networks: Using social network analysis to explore Extension's outreach. Journal of Extension, 49(6), 6FEA9. http://www.joe.org/joe/2011december/a9.php

Birk, S.M. (2005). Application of network analysis in evaluating knowledge capacity. In M.M. Durland \& K.A. Fredericks (Eds). Social network analysis in program evaluation. New Directions for Evaluation, 107, 69-79. San Francisco, CA: Jossey Bass. https://doi. org/10.1002/ev.162

Bryson, J.M., \& Patton, M.Q. (2010). Analyzing and engaging stakeholders. In J. Wholey, H. Hatry, \& K. Newcomer (Eds.), The handbook of practical program evaluation (3rd ed., pp. 30-54). San Francisco, CA: Jossey-Bass. 
Carrington, P.J., Scott, J., \& Wasserman, S. (Eds.) (2005). Models and methods in social network analysis. New York, NY: Cambridge University Press. https://doi.org/10.1017/ CBO9780511811395

Christakis, N.A., \& Fowler, J.H. (2009). Connected: The surprising power of our social networks and how they shape our lives. New York, NY: Little, Brown, and Company.

Cross, J.E., Dickmann, E., Newman-Gonchar, R., \& Fagan, J.M. (2009). Using mixedmethod design and network analysis to measure development of interagency collaboration. American Journal of Evaluation, 30(3), 310-329. https://doi. org/10.1177/1098214009340044

Donnelly, C.A., \& Searle, M. (2017). Optimizing use in the field of program evaluation by integrating learning from the knowledge field. Canadian Journal of Program Evaluation, 31(3). https://doi.org/10.3138/cjpe.366

Drew, R., Aggleton, P., Chalmers, H., \& Wood, K. (2011). Using social network analysis to evaluate a complex policy network. Evaluation, 17(4), 383-394. https://doi. org/10.1177/1356389011421699

Eglene, O., Dawes, S.S., \& Schneider, C.A. (2007). Authority and leadership patterns in public sector knowledge networks. American Review of Public Administration, 37(1), 91-113. https://doi.org/10.1177/0275074006290799

Fetterman, D.M., \& Wandersman, A. (2005). Empowerment evaluation principles in practice. New York, NY: Guilford Press.

Flood, J., Minkler, M., Lavery, S.H., Estrada, J., \& Falbe, J. (2015). The collective impact model and its potential for health promotion: Overview and case study of a healthy retail initiative in San Francisco. Health Education \& Behavior, 42(5), 654-668. https:// doi.org/10.1177/1090198115577372

Fredericks, K.A. (2005). Network analysis of disability demonstration program. In M.M. Durland \& K.A. Fredericks (Eds.). The use of network analysis in program evaluation: Trends, techniques, and applications. New Directions for Evaluation, 107, 55-68. San Francisco, CA: Jossey Bass.

Fredericks, K.A., Carman, J.G., \& Birkland, T.A. (2002). Program evaluation in a challenging authorizing environment: Intergovernmental and interorganizational factors. In R. Mohen, D.J. Bernstein, \& M.D. Whitsett (Eds.). Responding to sponsors and stakeholders in complex evaluation environments, New Directions for Evaluation, 95, 5-22. San Francisco, CA: Jossey Bass.

Gephi. (2017). Gephi: The open graph viz platform. Retrieved from https://gephi.org

Grunspan, D.Z., Wiggins, B.L., \& Goodreau, S.M. (2014). Understanding classrooms through social network analysis: A primer for social network analysis in education research. CBE Life Sciences Education, 13(2), 167-178. https://doi.org/10.1187/cbe.1308-0162

Hambrick, M.E. (2017). Sport communication research: A social network analysis. Sport Management Review, 20(2), 170-183. https://doi.org/10.1016/j.smr.2016.08.002

Hatry, H.P., \& Newcomer, K.E. (2016). Pitfalls in evaluation. In K. Newcomer, H. Hatry, \& J. Wholey (Eds.), The handbook of practical program evaluation (4th ed., pp. 701-724). San Francisco, CA: Jossey-Bass. 
Honeycutt, T.C., \& Strong, D.A. (2012). Using social network analysis to predict early collaboration within health advocacy coalitions. American Journal of Evaluation, 33(2), 221-239. https://doi.org/10.1177/1098214011424201

Johnson, J.A., Honnold, J.A., \& Stevens, F.P. (2010). Using social network analysis to enhance nonprofit organizational research capacity: A case study. Journal of Community Practice, 18(4), 493-512. https://doi.org/10.1080/10705422.2010.519683

Kapucu, N., Yuldashev, F., Demiroz, F., \& Arslan, T. (2010). Social network analysis (SNA): Applications in evaluating MPA classes. Journal of Public Affairs Education, 16(4), 541-563.

Knoke, D., \& Yang, S. (2008). Social network analysis (2nd ed.). Thousand Oaks, CA: Sage. https://doi.org/10.4135/9781412985864

Kottke, M., Levine, D., Schlanger, K., \& Nolte, K. (2015, April). A case report on Georgia's Public Private Partnership (P3) to prevent teen pregnancy: Harnessing the power of collective impact. Poster presentation at the NASPAG 29th Annual Clinical Research Meeting, Issues and Answers in Pediatric and Adolescent Gynecology, Orlando, FL.

Lahdelma, T., \& Laakso, S. (2016). Network analysis as a method of evaluating enterprise networks in regional development projects. Evaluation, 22(4), 435-450. https://doi. org/10.1177/1356389016667888

Ledley, T.S., Gold, A.U., Niepold, F., \& McCaffrey, M. (2014). Moving toward collective impact in climate change literacy: The Climate Literacy and Energy Awareness Network (CLEAN). Journal of Geoscience Education, 62(3), 307-318. https://doi. org/10.5408/13-057.1

Luke, D.A., Baumann, A.A., Carothers, B.J., Landsverk, J., \& Proctor, E.K. (2016). Forging a link between mentoring and collaboration: a new training model for implementation science. Implementation Science, 11(1), 137-149. https://doi.org/10.1186/s13012016-0499-y

Luque, J., Martinez Tyson, D., Lee, J.-H., Gwede, C., Vadaparampil, S., Noel-Thomas, S., \& Meade, C. (2010). Using social network analysis to evaluate community capacity building of a regional Community Cancer Network. Journal of Community Psychology, 38(5), 656-668. https://doi.org/10.1002/jcop.20386

Mertons, D.M. (2008). Transformative research and evaluation. New York, NY: Guilford Press.

Nahlen, B.L., \& Low-Beer, D. (2007). Building to collective impact: The Global Fund support for measuring reduction in the burden of malaria. American Journal of Tropical Medicine and Hygiene, 77(6), 321-327.

Newcomer, K.E., Hatry, H.P., \& Wholey, J.S. (2016). The handbook of practical program evaluation (4th ed.). San Francisco, CA: Jossey Bass.

Olsen, J.S., \& Olsen, G.M. (2014). Working together apart: Collaboration over the Internet. San Rafael, CA: Morgan \& Claypool.

ORA-PRO (2017). Netanomics: Social network analysis is changing the way people understand their network. Retrieved from http://netanomics.com/

Thomas, J.C. (2010). Outcomes assessment and program evaluation. In D. Renz (Ed.), The Jossey Bass handbook of nonprofit management and leadership (pp. 401-430). San Francisco, CA: Jossey Bass. 
UCINET (2017). Analytic Technologies: UCINET. Retrieved from http://www.analytictech. com/ archive/ucinet.htm

Woodland, R.H., \& Hutton, M.S. (2012). Evaluating organizational collaborations: Suggested entry points and strategies. American Journal of Evaluation, 33(3), 366-383. https://doi.org/10.1177/1098214012440028

\section{AUTHOR INFORMATION}

Joanne G. Carman is an associate professor in the Department of Political Science and Public Administration at the University of North Carolina-Charlotte.

Kimberly A. Fredericks is the Dean and Chair of Graduate Programs and an associate professor in the School of Management at The Sage Colleges. 